Article

\title{
Preparation and Characterization of Cellulose Triacetate as Support for Lecitase Ultra Immobilization
}

\author{
Francielle Batista da Silva ${ }^{1}$ (D), Wilson Galvão de Morais Júnior ${ }^{2}$, Cleuzilene Vieira da Silva ${ }^{1}$, \\ Andressa Tironi Vieira ${ }^{3}$, Antônio Carlos Ferreira Batista ${ }^{3}$, Anízio Márcio de Faria ${ }^{3}$ \\ and Rosana Maria Nascimento Assunção ${ }^{3, *}$ \\ 1 Laboratory of Polymers Recycling, Chemistry Institute, Federal University of Uberlândia, \\ Uberlândia 38408-144, MG, Brazil; fran_ciellesilva@yahoo.com.br (F.B.d.S.); cleuzilene@gmail.com (C.V.d.S.) \\ 2 Chemical Engineering Faculty, Federal University of Uberlândia, Uberlândia 38408-144, MG, Brazil; \\ wjunioreq@gmail.com \\ 3 Faculty of Integrated Sciences_FACIP, Federal University of Uberlândia, Ituiutaba 38304-402, MG, Brazil; \\ dessaqtironi@yahoo.com.br (A.T.V.); flashantonioc@gmail.com (A.C.F.B.); anizio@ufu.br (A.M.d.F.) \\ * Correspondence: rosanassuncao@gmail.com; Tel.: +55-034-3271-5251
}

Received: 25 September 2017; Accepted: 6 November 2017; Published: 16 November 2017

\begin{abstract}
The use of polymers as supports for enzyme immobilization is a strategy that enables to remove the enzymes from a chemical reaction and improve their efficiency in catalytic processes. In this work, cellulose triacetate (CTA) was used for physical adsorption of phospholipase Lecitase ultra (LU). CTA is more hydrophobic than cellulose, shows good performance in the lipases immobilization being a good candidate for immobilization of phospholipases. We investigated the immobilization of LU in CTA, the stability of the immobilized enzyme (CTA-LU) and the performance of CTA-LU using soybean oil as a substrate. LU was efficiently immobilized in CTA reaching $97.1 \%$ in $60 \mathrm{~min}$ of contact with an enzymatic activity of $975.8 \mathrm{U} \cdot \mathrm{g}^{-1}$. The CTA-LU system presents good thermal stability, being superior of the free enzyme and increase of the catalytic activity in the whole range of $\mathrm{pH}$ values. The difference observed for immobilized enzyme compared to free one occurs because of the interaction between the enzyme and the polymer, which stabilizes the enzyme. The CTA-LU system was used in the transesterification of soybean oil with methanol, with the production of fatty acid methyl esters. The results showed that CTA-LU is a promising system for enzymatic reactions.
\end{abstract}

Keywords: cellulose triacetate; immobilization; Lecitase ultra; methanolysis; soybean oil

\section{Introduction}

Cellulose acetate (CA) is an esterified cellulose derivative widely known for its numerous applications in membrane separation processes, production of matrices for controlled drug release (membranes or particles), protection of optical films, cigarette filters, among other applications [1-4]. Due to processability and biodegradable potential, an interesting field for CA applications is its use as a matrix for incorporation of bioactive species, by occlusion in the matrix or by physical adsorption [5-7].

This polymer can be produced from dissolving pulp or cellulose obtained from alternative lignocellulosic sources, through the reaction of cellulose with acetic anhydride and acetic acid catalyzed by sulfuric or perchloric acid. Figure 1 shows a scheme of the cellulose acetylation reaction. CA is formed by the modification of the hydroxyl groups of each glucose unit with an acetyl group. The average number of acetyl groups per glyosidic unit, or degree of substitution (DS), can be varied from 0 in the case of cellulose to 3 in the case of cellulose triacetate (CTA) and may also be 2.0-2.5 when 
cellulose diacetate (CDA) is formed [8]. According to Zhou and collaborators [9], cellulose acetylation dramatically alters the surface characteristics of the product by altering the strongly hydrophilic nature of the cellulose by decreasing its polarity. As the degree of substitution is increased, there is a consistent increase in the hydrophobic character of the material obtained.

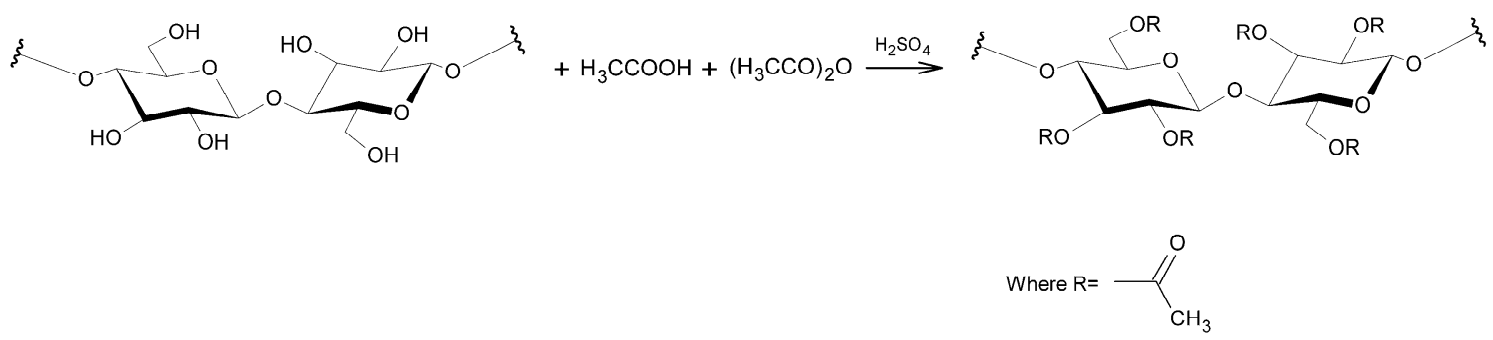

Figure 1. Scheme of acetylation of cellulose.

The use of natural supports, such as cellulose, for the immobilization of enzymes is advantageous since cellulose and its derivatives, particularly esterified ones, are biocompatible and present a balance of the hydrophilic/hydrophobic character important for effective enzyme adsorption and catalytic activity [10]. Considering that cellulose acetate has good processability, biocompatibility and possibility of changing the hydrophilic/hydrophobic character through acetylation/deacetylation [9], this polymer presents important properties for its use in the immobilization of bioactive species such as enzymes.

Several commercial immobilized enzymes have been used for various applications, including biodiesel production. Among the most cited are Novozyme 435 [11-15] and Lipozyme RM IM [16,17]. In contrast to the use of commercial biocatalysts, the development or modification of supports for the immobilization of enzymes (commercial or not) is an option that can minimize costs and even optimize reaction conditions depending on the enzymatic activity [18]. Research carried out using supports of mixtures of polylatic acid, chitosan and polyvinyl alcohol [19], cellulose nanocrystals [20], cellulose ester derivatives such as cellulose acetate (CA), cellulose acetate propionate (CAP) and cellulose acetate butyrate (CAB) films [21] were found in the literature. Moreover, Kosaka et al. [22], found that cellulose acetate films could serve as specific supports for lipases, when investigated the adhesion of bovine serum albumin (BSA) and lipase onto the cellulose esters films to evaluate the possibility of applying such films as selective support for biomolecules.

Despite the efficiency of lipases, and enzymes in general, factors such as cost and stability limit the use of enzymatic processes. Enzyme immobilization is a technique that minimizes this problem, since it allows reuse of the immobilized enzyme, an efficient separation of the reaction medium and is often able to improve enzyme activity [23]. Enzyme immobilization also can improve selectivity of proteins. Using different immobilization protocols is possible conferring different rigidity and distorting of enzyme and different physical properties [24-26]. Moreover, immobilization of enzymes can minimize inhibition effects, distorting or blocking active center of enzymes and reducing inhibition caused by some substrate, component of the bulk medium or product of reaction [27].

The simplest form of lipase immobilization is by adsorption onto a solid support via intermolecular forces. Physical adsorption is a popular technique because it is easy to perform, inexpensive and requires only mild chemical conditions [28]. An interesting fact about lipase is that, while its substrates are hydrophobic lipids, it is soluble in water, been fairly hydrophilic proteins with an hydrophobic area surrounding the catalytic site [29]. This means that the catalytic site is hidden within the structure of this monomeric protein which is exposed at the interface of the lipid-water interface. This feature is called interfacial activation. This mechanism suggests the presence of a lid that, when closed, covers the catalytic site and makes the enzyme inactive, but in the presence of the interface, undergoes a conformational change and opens to reveal the active site [30]. Appling a hydrophobic support as support for lipases, that resembles the surface of the drops of substrates, 
and low ionic strength, the enzymes become selectively immobilized on these supports. Other water soluble proteins are not adsorbed on the support under these conditions. Immobilized enzymes usually exhibit a significantly enhanced enzyme activity by the interfacial activation [31,32]. Lecitase Ultra (LU) is an artificial phospholipase developed primarily for degumming processes [33]. This enzyme is obtained from the fusion of the lipase genes of Thermomyces lanuginosus (for good stability) and of the phospholipase Fusarium oxysporum (to obtain phospholipase activity). In some respects, it behaves as a standard lipase with the ability to be adsorbed onto hydrophobic surfaces of low ionic strength (e.g., hydrophobic supports) and exhibits broad specificity [34]. This enzyme is known to have sn-1,3 regiospecificity in relation to triacylglycerol [35]. Lecitase ultra has been largely used for degumming oil [35-39], but also for diacylglycerols and monoacylglycerols production [33,40-42], enantioselective reactions $[43,44]$, and in methyl esters production [45,46]. Many papers studied immobilization of this enzyme and improve of stability and activity of this phospholipase [34,47]. There are few studies dealing with the production of methyl esters from enzymatic transesterification using LU phospholipase $[45,46]$.

In this study, the immobilization of LU phospholipase was performed in a CTA suspension, used as a support, via physical adsorption. Although hydrophobic characteristics that favors the physical adsorption of lipase, few studies have been carried out using CA for lipase immobilization [48,49].

The objective of this work is to prepare a stable support from Kraft pulp that can immobilize LU phospholipase by physical adsorption and to employ the immobilized enzyme in fatty acid methyl ester (FAME) production from soybean oil.

\section{Material and Methods}

\subsection{Materials}

The enzyme Lecitase Ultra (Novozymes) was donated by LNF Latino Americana Company (Bento Gonçalves, Rio Grande do Sul, Brazil). The bleached Kraft pulp, originating from eucalyptus, was donated by Suzano (Americana, São Paulo, Brazil). Refined soybean oil was purchased at a local market. Other reagents and standards used for the synthesis and characterization of cellulosic derivatives are analytical or HPLC grade.

\subsection{Production of $C A$ and Characterization of the Material Obtained}

CA was produced as previously described with some modifications [50]. $50.0 \mathrm{~mL}$ of glacial acetic acid was added to $2.00 \mathrm{~g}$ of Kraft pulp. The mixture was stirred for $30 \mathrm{~min}$ at room temperature. Then a solution containing $0.16 \mathrm{~mL}$ of concentrated $\mathrm{H}_{2} \mathrm{SO}_{4}$ in $18.0 \mathrm{~mL}$ of glacial acetic acid was added and stirred for $25 \mathrm{~min}$ at room temperature. The mixture was filtered. Acetic anhydride $(64.0 \mathrm{~mL})$ was added to the filtrate with stirring and the filtrate was returned to the starting flask with the material. The solution was stirred for another $30 \mathrm{~min}$ and allowed to stand. After $5 \mathrm{~h}$, distilled water was added to the reaction medium until no further precipitate was formed. The mixture was vacuum filtered by washing with distilled water to neutral $\mathrm{pH}$. The material was oven dried for $90 \mathrm{~min}$ at $105^{\circ} \mathrm{C}$.

The samples were characterized by absorption spectroscopy using FTIR. The samples were analyzed as $\mathrm{KBr}$ pellets at the ratio of 1:100 $(w / w)$ on a Shimadzu IR Prestige-21 FTIR absorption spectrometer. Thirty-two scans with a resolution of $4 \mathrm{~cm}^{-1}$, in the range of $500-4000 \mathrm{~cm}^{-1}$ were made.

The degree of substitution of the material obtained was calculated from the ratio between the absorbances of the drawstring $\mathrm{C}=\mathrm{O}\left(1750 \mathrm{~cm}^{-1}\right)$ and $\mathrm{OH}\left(3400 \mathrm{~cm}^{-1}\right)$. According to Hurtubise [51] the ratio between these absorbances is related to the percentage of acetyl groups $(A G)$ of $C A(\% A G)$. The value of the percentage of acetyl groups relates to DS according to Equations (1) and (2) [52].

$$
\% A G=43.69\left(1-e^{-0.974 x}\right)^{2.153}
$$

where $x=$ ratio between the absorbances of the drawstring $\mathrm{C}=\mathrm{O}\left(1750 \mathrm{~cm}^{-1}\right)$ and $\mathrm{OH}\left(3400 \mathrm{~cm}^{-1}\right)$. 


$$
D S=\left(\frac{162 \times \% G A}{43 \times 100-42 \times \% G A}\right) 100
$$

Images of Kraft pulp and CA were obtained by SEM. The equipment used was a Carl Zeiss model EVO 10 MA scanning electron microscope. The samples were previously metallized with a thin gold layer using a Sputtering Leica.

\subsection{Immobilization of LU on CTA}

One gram of CTA was added to $10 \mathrm{~mL}$ of LU solution $30 \%(v / v)(335 \mathrm{U} / \mathrm{mL}, 5.6 \mathrm{mg} / \mathrm{mL}$ protein) in a $25 \mathrm{mM}$ sodium phosphate buffer $\mathrm{pH}$ 7. The suspension was maintained under static conditions at $4{ }^{\circ} \mathrm{C}$ [53]. The enzymatic activities of the suspension and also of the supernatant (without the presence of the support) were measured periodically to follow the immobilization process. After immobilization, the support was washed with deionized water, vacuum filtered and stored at $4{ }^{\circ} \mathrm{C}$ for later use. The biocatalyst obtained was called CTA-LU.

Yield of immobilization (YI) was defined as the ratio between the amount of immobilized enzyme and the amount of enzyme offered to immobilization (\% immobilization).

\subsection{Enzymatic Activity Assay and Protein Dosage}

The assays were performed by measuring absorbance at $410 \mathrm{~nm}$, which is produced by the release of $p$-nitrophenyl palmitate ( $p$-NPP). The samples were incubated in a $50 \mathrm{mM}$ sodium acetate buffer at $\mathrm{pH} 5$, containing $0.05 \%(w / v)$ arabic gum, $0.25 \%(v / v)$ Triton X-100 and $p$-NPP solution, consisting of $3 \mathrm{mg} p$-NPP $/ \mathrm{mL}$ of 2-propanol. Aliquots of the samples $(0.1 \mathrm{~mL}$ of free enzyme or $0.1 \mathrm{~g}$ of immobilized enzyme) were added to the reaction solution in a ratio of $1: 9(\mathrm{v} / \mathrm{v})$ and the reaction was controlled for $10 \mathrm{~min}$ at $50{ }^{\circ} \mathrm{C}$. After this time, samples were taken at $92{ }^{\circ} \mathrm{C}$ for $2 \mathrm{~min}$ and then in the ice bath with the addition of saturated sodium borate solution. The absorbance was measured (PG Instruments T70 Spectrophotometer, Lutterworth, UK). One unit of enzyme is equivalent to the release of $1 \mu \mathrm{mol}$ of $p$-nitro phenol $(p-\mathrm{NP})\left(\varepsilon=7.93 \mathrm{umol} \cdot \mathrm{cm}^{-1}\right)$ per minute by $1 \mathrm{~mL}$ of free enzyme or per gram of immobilized enzyme (weight of matrix included). The methodology is an adaptation from Pencreach and Baratti [54].

The protein dosage of the enzyme was determined according to the method of Bradford [55] using a previously made calibration curve.

\subsection{Biochemical Characterization of Lecitase Ultra Immobilized in CTA (CTA-LU)}

\subsubsection{Effect of $\mathrm{pH}$ and Temperature on Stability of Soluble LU and CTA-LU}

Aiming to evaluate $\mathrm{pH}$ effect on activity of LU, free and immobilized lipase were kept at room temperature for $2 \mathrm{~h}$ in a $50 \mathrm{mM}$ sodium citrate buffer (at $\mathrm{pH} \mathrm{3,4}$ and 5); a $50 \mathrm{mM}$ phosphate buffer (at pH 6, 7 and 8); and a $50 \mathrm{mM}$ sodium bicarbonate buffer (at pH 9 and 10). Enzyme activity was measured according to the methodology described in Section 2.4.

Free and immobilized LU were diluted in $50 \mathrm{mM}$ phosphate buffer at $\mathrm{pH} 7$, then incubated at different temperatures $\left(30,35,40,45\right.$ and $\left.50{ }^{\circ} \mathrm{C}\right)$ for $8 \mathrm{~h}$, for evaluate thermal stability of lipase. The enzyme activity was measured according to Section 2.4.

The thermal inactivation of the enzyme was evaluated through a pseudo first order kinetic model according to Equation (3) [56]:

$$
\ln \left(\frac{A_{t}}{A_{0}}\right)=-k_{d} \times t
$$

where $A_{t}$ is the enzyme activity at treatment $t$, time (h), $A_{0}$ is the initial enzyme activity and $k_{d}$ is inactivation rate constant at the temperature studied.

The $k_{d}$, for different temperatures were estimated by linear regression analysis of the natural logarithm of residual activity versus time. 


\subsubsection{Effect of Organic Solvents on Stability of CTA-LU}

The effect of some solvents (methanol, ethanol, iso-propanol, $n$-hexane) was studied on activity of immobilized lipase. The immobilized lipase was separately incubated with each of the selected solvents (added in $50 \mathrm{mM}$ phosphate buffer $\mathrm{pH}$ 7) at room temperature for $30 \mathrm{~h}$. The enzyme activity was evaluated according to Section 2.4.

\subsubsection{Desorption of LU from CTA}

CTA-LU samples were added to solutions containing Triton X-100 in a $25 \mathrm{mM}$ sodium phosphate buffer at $\mathrm{pH} 7.0$ and $25^{\circ} \mathrm{C}$, at concentrations of $0.02 \%, 0.2 \%, 0.5 \%$ and $1.0 \%(v / v)$. The samples were mechanically stirred for $50 \mathrm{~min}$ and the enzymatic activities were calculated as described in Section 2.4.

\subsection{Reusability of CTA-LU}

Derivative reuse was performed in batch assays by incubating $0.1 \mathrm{~g}$ of CTA-LU with $0.90 \mathrm{~mL}$ of $p$-NPP solution (prepared as previously described). After 10 min of reaction, samples were taken at $92{ }^{\circ} \mathrm{C}$ for $2 \mathrm{~min}$ and then in the ice bath with the addition of saturated sodium borate solution. The released $p$-NP was measured at $410 \mathrm{~nm}$. After each cycle, CTA-LU was washed with $25 \mathrm{mM}$ sodium phosphate buffer $\mathrm{pH}$ 7.0, filtrated and added to a new hydrolysis cycle with new substrate solution. The activity after each cycle was expressed in relation to the activity after the first cycle.

\subsection{Methanolysis Product of Soybean Oil Catalyzed by LU Immobilized in CTA}

Transesterification reactions were performed with soybean oil, at a molar ratio of 1:4 (oil/methanol), 20\% (\% by oil wt.) of CTA-LU, 15\% (\% by oil wt.) of water and 3.3\% (by oil wt.) of $n$-hexane. Reactions were carried out under magnetic stirring ( $250 \mathrm{rpm})$, at $35^{\circ} \mathrm{C}$ and finalized after $24 \mathrm{~h}$. The samples were centrifuged and the upper phase was collected and analyzed by chromatography. No purification step was performed after the reaction.

The molar ratio of soybean oil was calculated by Equation (4):

$$
M_{o i l}=3\left(\frac{\sum \% F A \times M_{F A}}{\sum \% F A}\right)+38.04
$$

where $M_{\text {oil }}$ : molar mass of soybean oil; \%FA: molar percent of fatty acids; $M_{F A}$ : molar mass of fatty acids; 38.04: difference between the molar mass of glycerin and the three water molecules that replace glycerin.

Analyses of fatty acid methyl esters (FAMEs) were conducted by gas chromatography in an Shimadzu gas chromatograph (GC2010-Plus) equipped with a flame ionization detector (FID) and RTX-WAX capillary column $(30 \mathrm{~m} \times 320 \mu \mathrm{m} \times 0.25 \mu \mathrm{m})$. The split ratio was 1:10 and helium was used as the carrier gas. The amount of sample injected was $1 \mu \mathrm{L}$ and the total time of analysis was $15 \mathrm{~min}$. An analytical standard FAME mix (C4-C24) from Supelco was used to identify the peaks at different retention times. Peak identities were confirmed by analyzing the synthesis product in a gas chromatography system equipped with a Shimadzu mass spectrometer, GCMS-QP2010 (Columbia, MD, USA) model. The FAME content was calculated using the compensated normalization method with internal standardization based on the European standard EN 14103. Methyl heptadecanoate was used as the internal standard in this analysis.

\section{Results and Discussion}

\subsection{Production and Characterization of $C A$}

For production of cellulose acetate, the homogeneous process was used. In the homogeneous process, in which non-swelling agents are not employed, cellulose triacetate (CTA) is solubilized in the reaction medium as it is produced. An important characteristic of cellulosic derivatives is 
the possibility of mediating, by chemical modification, their hydrophilic/hydrophobic character. This property is important because lipases have high affinity for hydrophobic supports and in various cases immobilization in this type of support increase activity of enzymes [29]. In addition, cellulose acetate can be obtained from any cellulosic source if the residues are purified and withdrawn from lignin and hemicelluloses [1,8,50,57-59].

The CA synthesis was confirmed by FTIR analysis. Figure 2 shows infrared spectra of the Kraft pulp and CA obtained.

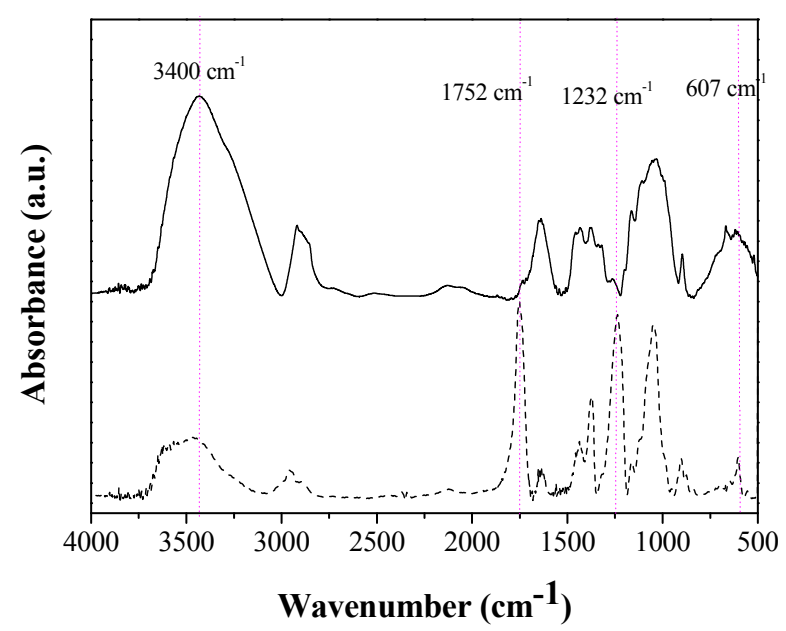

Figure 2. Infrared spectrum obtained for Kraft pulp (straight line) and cellulose triacetate (dashed line).

It can be observed from Figure 2 that cellulose was acetylated. This is confirmed in the CA spectra by the decrease in the peak intensity close to $3400 \mathrm{~cm}^{-1}$, the associated stretching of $\mathrm{OH}$ groups and the appearance of the ester carbonyl peak at $1752 \mathrm{~cm}^{-1}$ due to $\mathrm{O}=\mathrm{CO}-\mathrm{CH}_{3}$ stretching of acetate and the CO stretching of acetyl groups at 1232 and $607 \mathrm{~cm}^{-1}$. This is the strongest evidence that the material has been acetylated, since the other peaks are common to both materials. The degree of substitution obtained from the ratio between the absorbance (Equations (1) and (2), Section 2.2) of the $\mathrm{C}=\mathrm{O}$ stretching peaks and the $\mathrm{OH}$ stretching bands was 2.7, indicating that the material obtained is cellulose triacetate (CTA). Moreover material obtained presents solubility in dichloromethane [60-62].

The images obtained by scanning electron microscopy (SEM), presented in Figure 3, indicate the structure modification when comparing Kraft pulp (Figure 3A) with CTA (Figure 3B). There is a modification in the structure of the fibers of the feedstock when the material is acetylated. During synthesis, fiber swelling occurs due to the presence of glacial acetic acid and hydrolysis, which may occur due to the presence of the sulfuric acid catalyst. These processes modify the morphology of the fibers, which become more disorganized and undergo a defibrillation process.

The chemical modification of the Kraft pulp through the reaction of the hydroxyl groups of the cellulose with the acetic groups of the acetic anhydride leads to the production of the cellulose triacetate, a cellulosic derivative more hydrophobic than the original cellulose. Thus, the CTA would be suitable for the immobilization of lipases by physical adsorption, since it resembles the substrates of the lipases, allowing them to readily attach to the support. 

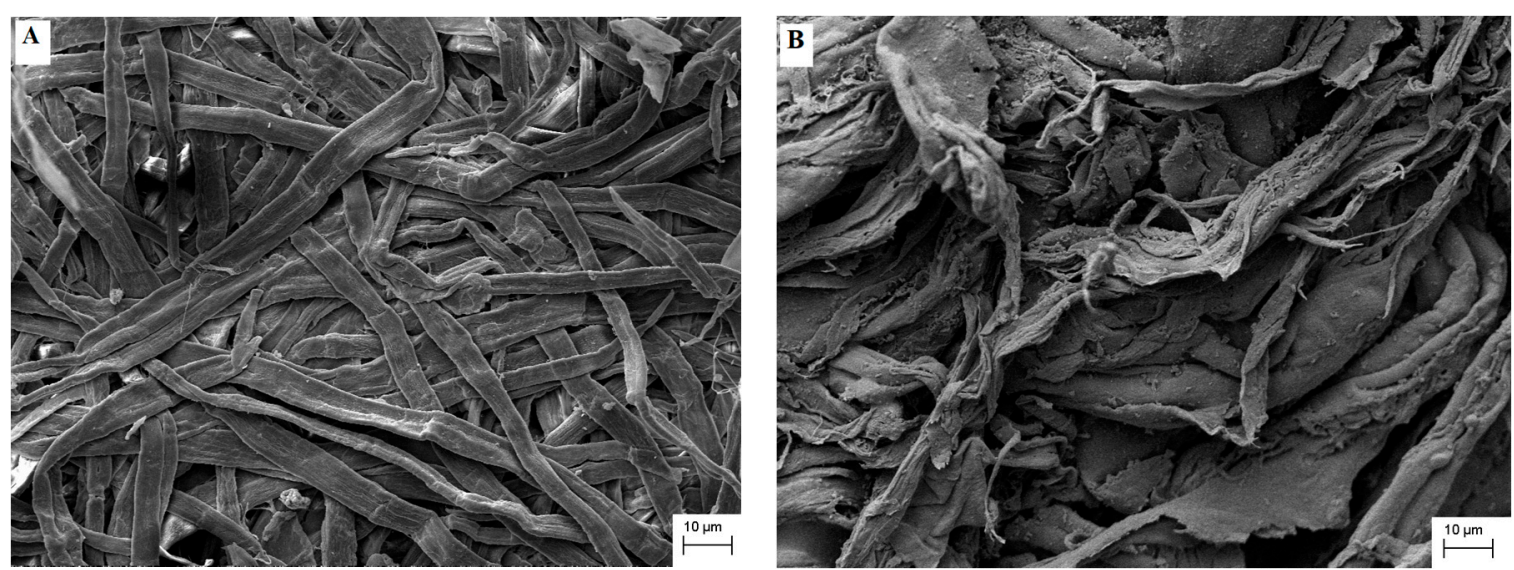

Figure 3. Scanning electron microscopy for samples of (A) Kraft pulp and (B) CTA.

\subsection{Enzyme Immobilization}

LU was immobilized on CTA with a maximum immobilization yield of $97.1 \pm 4.4 \%$ after 60 min (Figure 4) presenting a specific activity of $975.8 \mathrm{U} \cdot \mathrm{g}^{-1}$ support. The immobilization of LU in CTA probably occurred via interfacial activation. This is a peculiar mechanism of lipases, which relates to the open form of the lipase when in contact with a hydrophobic surface in low ionic strength medium [63].

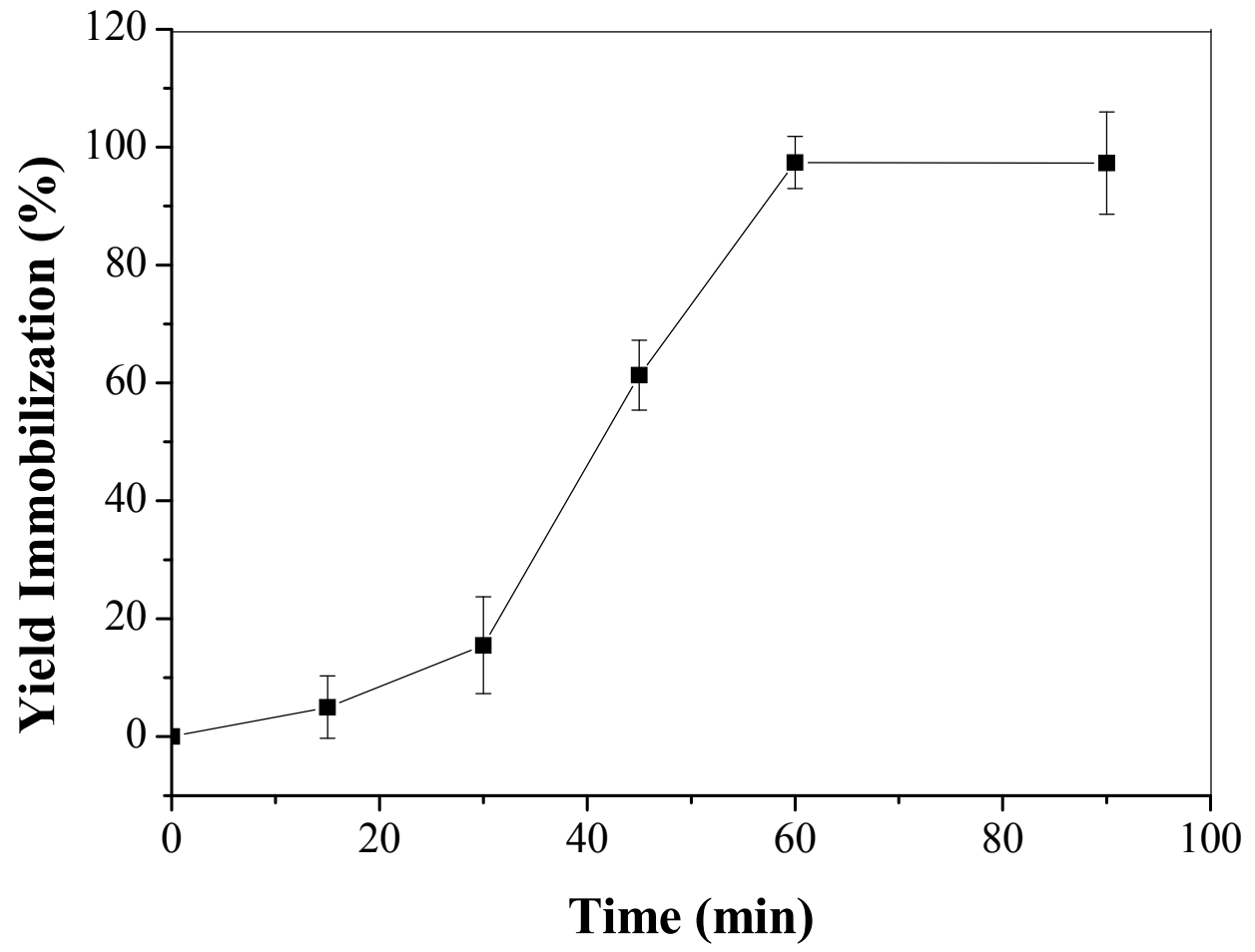

Figure 4. Yield of immobilization versus incubation (immobilization) time for LU in CTA support. The error bars are derived from triplicates.

Figure 5A shows the spectra in the infrared region for the CTA and CTA-LU. The biocatalyst retains much of the characteristics of the original CTA, except for the $\mathrm{O}-\mathrm{H}$ stretch region and a slight change in the region between 1660 and $1500 \mathrm{~cm}^{-1}$. The band at approximately $3400 \mathrm{~cm}^{-1}$ exhibits a typical O-H stretching profile attributed to adsorbed water and N-H stretching, typical of the 
polypeptide structure of the enzymes, best seen in Figure 5B. The polypeptides have a characteristic structure related to the presence of the amide group, which can be classified as amide I and amide II. The amide-related band I is attributed to the carbonyl stretch, $\mathrm{C}=\mathrm{O}$, of the $(\mathrm{CONH})$ group and appears between 1700 and $1650 \mathrm{~cm}^{-1}$, as can be seen in Figure $5 \mathrm{C}$. The band at $1650 \mathrm{~cm}^{-1} \mathrm{can}$ also be influenced by the presence of water, since the angular deformation of a water molecule appears between 1640 and $1645 \mathrm{~cm}^{-1}$ [64].
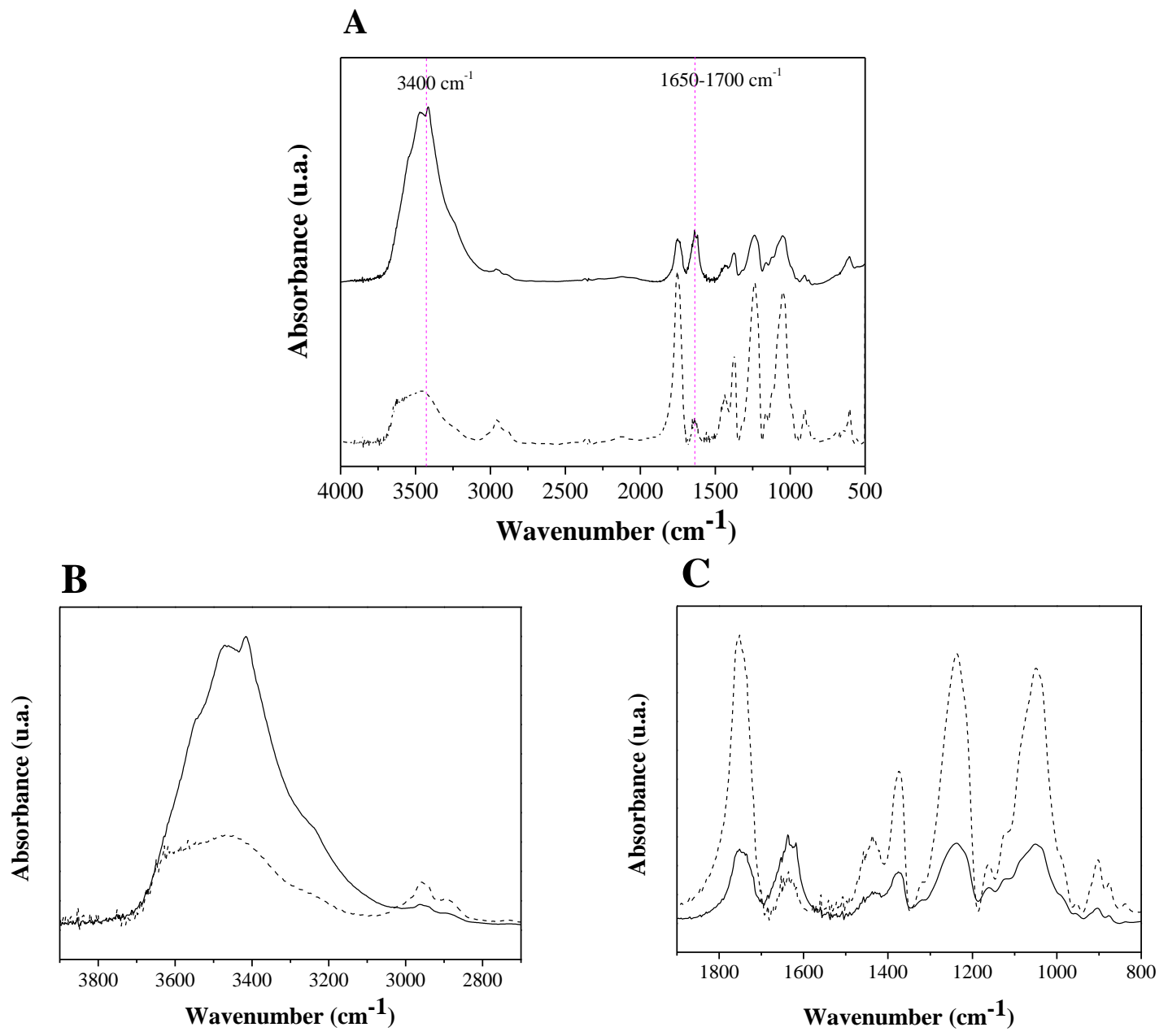

Figure 5. Spectrum in the infrared region for CTA (dashed line) and CTA-LU (straight line) (A) complete spectrum; $(\mathbf{B}, \mathbf{C})$ cutting of the most important regions of the spectrum.

Although the contribution of the bands of the enzyme is small, it is sufficient to indicate their immobilization in CTA. This technique is usually used to confirm enzyme presence in synthetized supports $[65,66]$.

Figure 6 shows an SEM image of CTA-LU sample, CTA with immobilized enzyme. The sharp structure of the fibers is apparent in the original cellulose (Figure 3A) and appears in a disorganized and more compacted form in CTA (Figure 3B). The structure is less evident and more than immobilized enzyme). This behavior may be associated with the processing of immobilization where possible swelling and drying processes lead to aggregation of the CTA. 


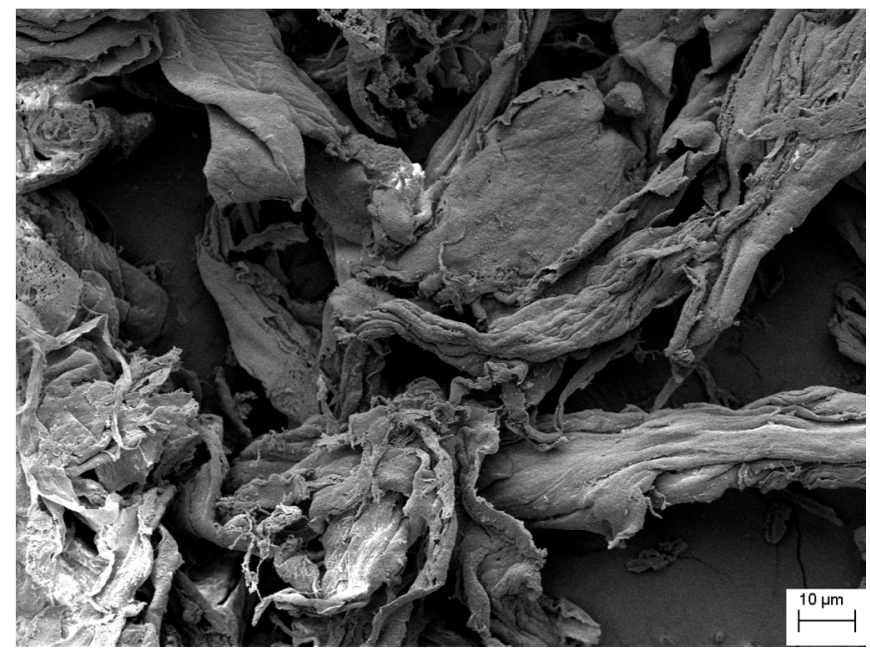

Figure 6. SEM image of CTA-LU.

\subsection{Biochemical Characterization of CTA-LU}

\subsubsection{Temperature and pH Effects on Stability of Soluble LU and CTA-LU}

The thermal stability of Lecitase Ultra and immobilized lipase were studied by measuring residual enzyme activity as function of temperature for $8 \mathrm{~h}$. Figure 7 shows the curve patterns of residual activity versus time for different temperatures $\left(30,35,40,45\right.$ and $\left.50{ }^{\circ} \mathrm{C}\right)$.
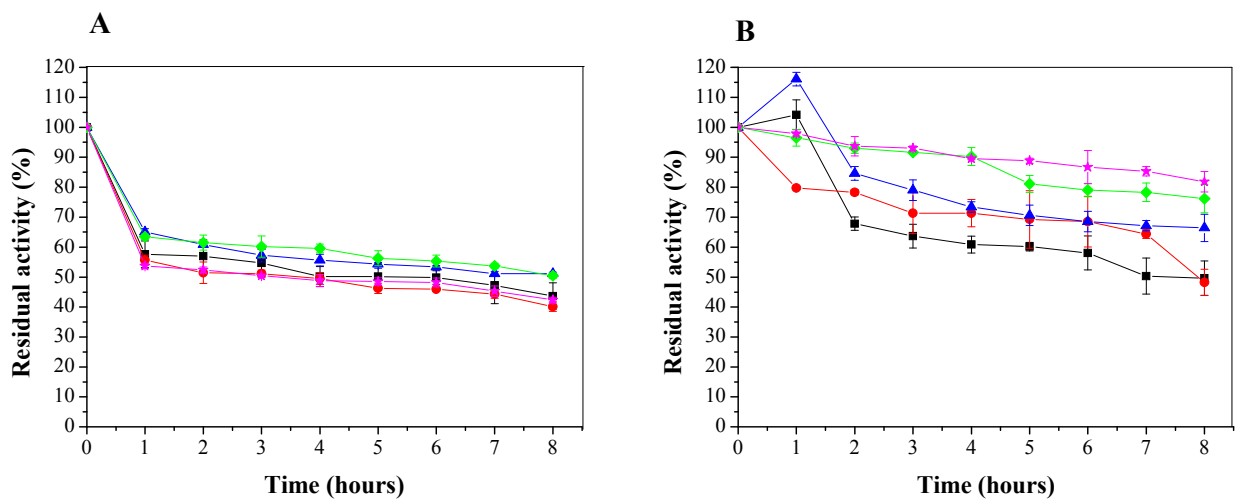

Figure 7. Thermal stability of free (A) and immobilized lipase $(\mathbf{B})$ at temperatures of $30{ }^{\circ} \mathrm{C}(\boldsymbol{\Delta}), 35^{\circ} \mathrm{C}(\diamond)$, $40^{\circ} \mathrm{C}(\star), 45^{\circ} \mathrm{C}(\mathbf{\square})$ and $50^{\circ} \mathrm{C}(\bullet)$ in $25 \mathrm{mM}$ sodium phosphate ${ }^{\prime}$ buffer, $\mathrm{pH}$ 7. The error bars are derived from triplicates.

Figure 7A shows the effect of temperature on the activity of free lipase. It was observed that with one hour of incubation at 30 and $35^{\circ} \mathrm{C}$, the enzyme undergoes an inactivation of approximately $35 \%$, with a loss of activity close to $50 \%$ after $8 \mathrm{~h}$. At 40,45 and $50{ }^{\circ} \mathrm{C}$, the inactivation is shown to be $45 \%$, $43 \%$ and $47 \%$, respectively.

The effect of temperature on the activity of immobilized lipase was also studied (Figure 7B). At $30{ }^{\circ} \mathrm{C}$, it was noted that in the first hour of the experiment, the immobilized LU in the CTA support underwent activity increase and enzyme presented a final residual enzyme activity of $66 \%$ after $8 \mathrm{~h}$ of incubation. At $45{ }^{\circ} \mathrm{C}$, similar behavior was observed: an activity increase in the first hour of the experiment, showing a final residual enzymatic activity of $48 \%$, which is close to that obtained at $50{ }^{\circ} \mathrm{C}$. Looking at the results, it is noticeable that the immobilized enzyme is more stable at 35 and $40{ }^{\circ} \mathrm{C}$ with an inactivation of $24 \%$ and $19.3 \%$, respectively, after $8 \mathrm{~h}$. 
The increase in temperature generally causes an increase in reaction rate, with or without catalysts. However, enzymes are biological systems of complex nature, with catalytic activity dependent on their tertiary structure and this must be taken into account.

Table 1 shows the values of $k_{d}$ for free and immobilized enzyme. In both cases, changes in $k_{d}$ values are observed for the evaluated temperatures. The changes in $k_{d}$ values are related to the occurrence of two competitive processes: (i) the increase of the catalyzed reaction rate due to the increase in temperature and (ii) at high temperatures, the reduction of the reaction rate due to inactivation of the enzyme. Thus, the increase of $k_{d}$ indicates that the inactivation of the enzyme is predominant at the evaluated temperature and in this condition the enzymatic reaction will occur slowly.

Table 1. Thermal denaturation kinetic parameters for free and immobilized lipase.

\begin{tabular}{ccccc}
\hline & \multicolumn{2}{c}{ Free Enzyme } & \multicolumn{2}{c}{ Immobilized Enzyme } \\
\hline $\mathbf{T}\left({ }^{\circ} \mathbf{C}\right)$ & $\boldsymbol{k}_{\boldsymbol{d}}\left(\mathbf{h}^{-\mathbf{1}}\right)$ & $\mathbf{R}^{\mathbf{2}}$ & $\boldsymbol{k}_{\boldsymbol{d}} \mathbf{( \mathbf { h } ^ { - \mathbf { 1 } } )}$ & $\mathbf{R}^{\mathbf{2}}$ \\
\hline 30 & $0.062 \pm 0.0013$ & 0.6591 & $0.050 \pm 0.0058$ & 0.9199 \\
35 & $0.058 \pm 0.0039$ & 0.6791 & $0.036 \pm 0.0055$ & 0.9568 \\
40 & $0.069 \pm 0.0028$ & 0.5706 & $0.024 \pm 0.0013$ & 0.9825 \\
45 & $0.071 \pm 0.0091$ & 0.6526 & $0.076 \pm 0.0067$ & 0.8887 \\
50 & $0.077 \pm 0.0057$ & 0.6506 & $0.064 \pm 0.0074$ & 0.8225 \\
\hline
\end{tabular}

For free enzyme, in Figure 7A and in Table 1, the values of residual activity (\%) are close, as well as the data of $k_{d}$ undergoes minor changes in the incubation temperatures between 30 and $35^{\circ} \mathrm{C}$. This result indicates that, for this condition, the stability of the enzyme is maintained. For temperatures higher than $40{ }^{\circ} \mathrm{C}$, there is a decrease in residual activity (\%) accompanied by a small increase in $k_{d}$ values, which, although obtained from a fragile linear adjustment of the experimental data, shows a tendency to deactivate the free enzyme. This effect can be confirmed when we observe the data obtained for immobilized enzyme. The effect of the presence of the support is evident, since the linear fits for the calculation of the deactivation constant present less dispersion and a better tendency to linearity. In Figure 7B and in Table 1, an increase in the residual activity that reaches the best condition at $40{ }^{\circ} \mathrm{C}$ is observed at temperatures above this the system presents a more pronounced drop in the residual activity (\%) and an increase of $k_{d}$ values, indicating that the system becomes thermally unstable. Since the CTA-LU system presents better adjustment of the experimental data for incubation temperatures in which the system is more stable and loses this condition with the increase of the incubation temperature to values higher than $40{ }^{\circ} \mathrm{C}$. In this sense, the immobilization of the enzyme in the support stabilizes the active site and avoids the change of the tertiary structure in the considered temperature range.

The results obtained in this work were similar to those of Mishra et al. (2009), studied the thermal stability of purified LU by measuring residual activity after incubation at a given temperature for $1 \mathrm{~h}$. In the study, the incubation temperature was varied between 30 and $70{ }^{\circ} \mathrm{C}$. The results showed that the enzyme is stable up to $50{ }^{\circ} \mathrm{C}$ and loses its activity rapidly at $60^{\circ} \mathrm{C}$, with a residual activity of about $10 \%$. For the incubation temperatures between 30 and $40{ }^{\circ} \mathrm{C}$, the residual activities are close and presents values between $80 \%$ and $90 \%$.

The enzyme activity was dependent on temperature, as illustrated in Figure 8. LU immobilized in CTA exhibited maximum activity at $40^{\circ} \mathrm{C}$, the same temperature described in literature for free enzyme [35]. 


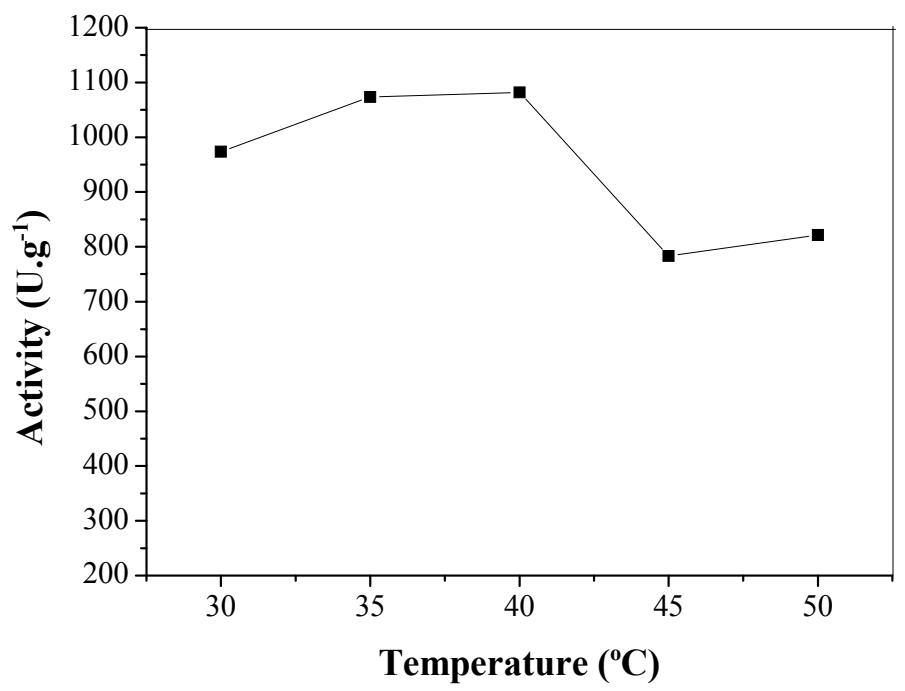

Figure 8. Temperature optimum of CTA-LU with lipase activity measured at pH 7.

The results of the $\mathrm{pH}$ study, shown in Figure 9, indicate that compared to soluble LU, the immobilized lipase underwent activity increase at all studied $\mathrm{pHs}$. Moreover, the highest $\mathrm{pH}$ values (more alkaline) this effect is more accentuated. LU immobilized on Octyl-Sepharose also showed increased activity with an increase in $\mathrm{pH}$ [67].

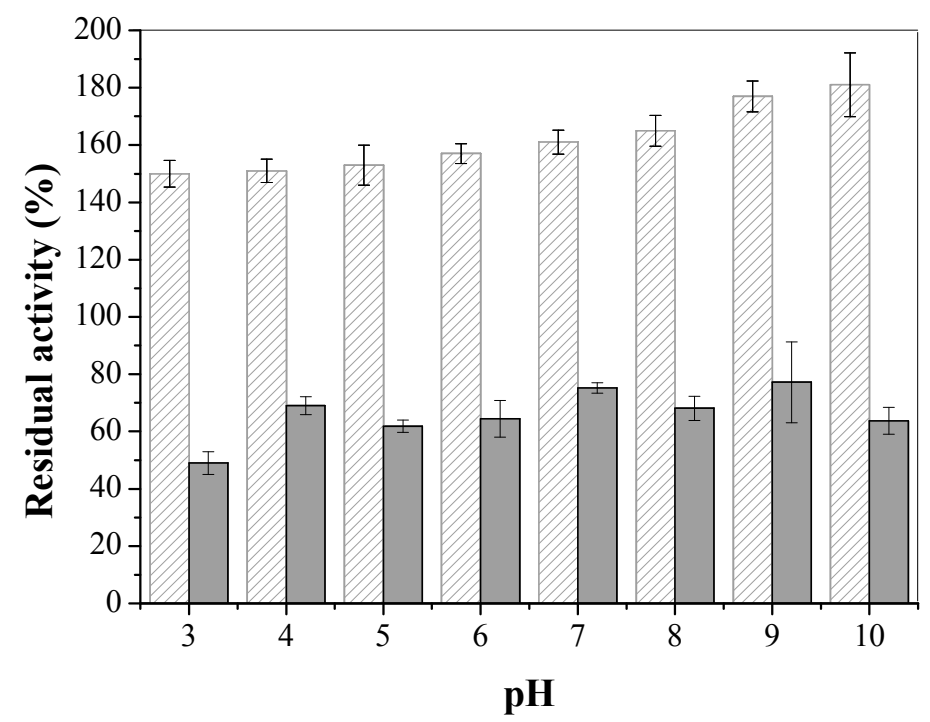

Figure 9. Residual activity (\%) related to $\mathrm{pH}$ variation for free LU (solid) and immobilized LU (striped) in CTA. The error bars are derived from triplicates.

\subsubsection{Effect of Organic Solvents on Stability of CTA-LU}

The effect of organic solvents on the stability of CTA-LU using ethanol, methanol, propanol and hexane at a final concentration of $50 \%(v / v)$ was studied under mechanical stirring for $30 \mathrm{~h}$ at $25^{\circ} \mathrm{C}$. Figure 10 shows the stability profiles of the CTA-LU in the presence of the different organic solvents. CTA-LU underwent activity increase in the presence of hexane after $6 \mathrm{~h}$ incubation. At $24 \mathrm{~h}$, the immobilized LU presented similar relative activity in all the studied organic solvents, with an inactivation of approximately $38 \%$. 


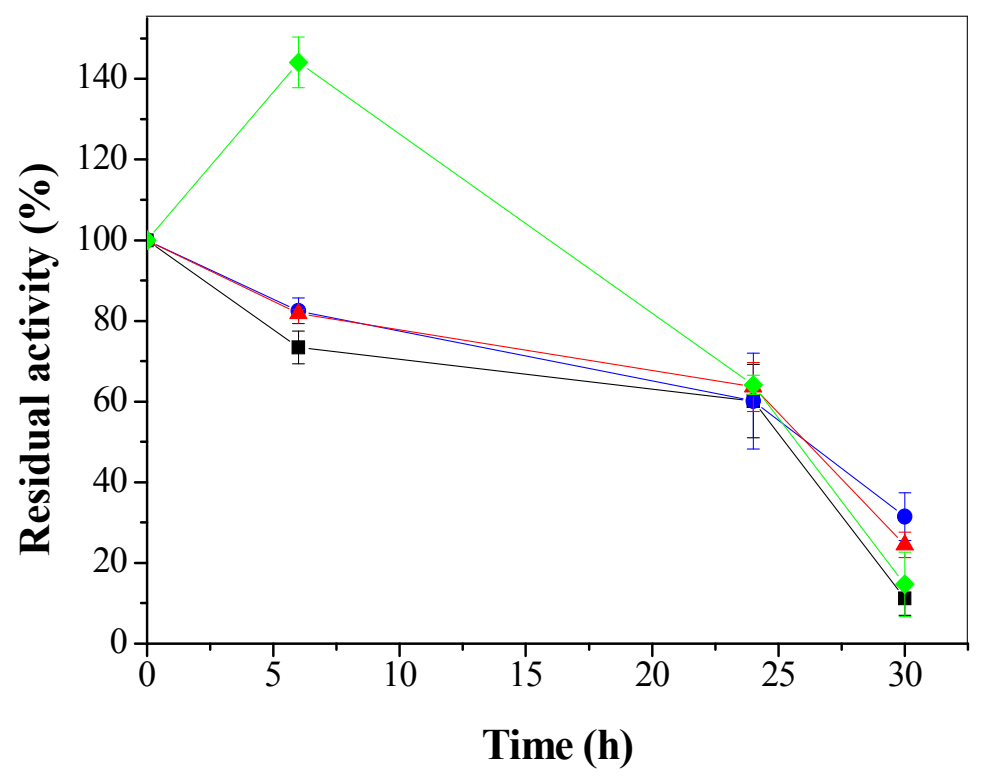

Figure 10. Residual activity (\%) in relation to the presence of solvents: methanol ( $\square)$, ethanol $(\bullet)$, propanol $(\boldsymbol{\Delta})$ and hexane $(\diamond)$ in the immobilized LU for CTA. The error bars are derived from triplicates.

The use of organic solvents in the enzymatic synthesis of FAME reduces system viscosity and aids mass transfer, improving the mutual solubility of hydrophobic triglycerides and hydrophilic alcohols, protecting the enzymes from denaturation by high concentrations of alcohols and ensuring transesterification with the addition of alcohol in only one step. Some organic solvents used for this application are isooctane, $n$-heptane, petroleum ether, $n$-hexane, cyclohexane and tert-butanol. Through the use of these solvents, an increase in the rate of transesterification is also observed [68].

\subsubsection{Enzymatic Desorption}

Desorption of LU was assisted by the presence of aqueous solutions of Triton X-100 at concentrations of $0.02 \%, 0.2 \%, 0.5 \%$ and $1.0 \%(v / v)$, the results can be seen in Figure 11 .

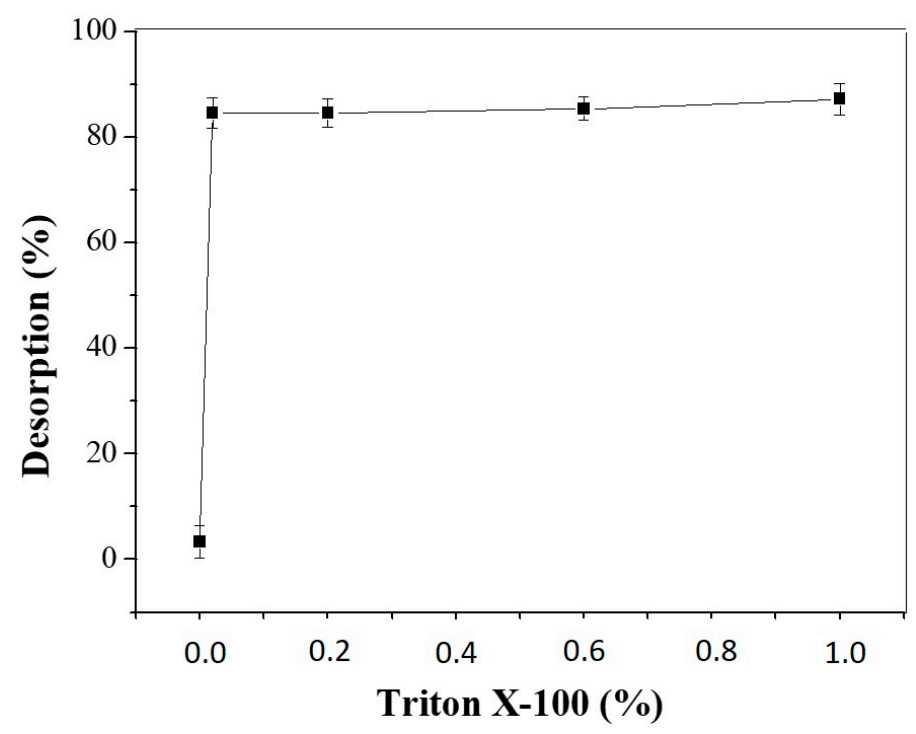

Figure 11. Desorption of the enzyme LU immobilized in CTA using Triton X-100 at concentrations of $0.02 \%, 0.2 \%, 0.5 \%$ and $1.0 \%(v / v)$. The error bars are derived from triplicates. 
It was observed that $84.5 \%$ of the lipase was desorbed from the support with a $0.02 \%$ concentration solution of Triton X-100. Increasing the concentration of the surfactant solution to $0.2 \%, 0.5 \%$ and $1.0 \%$, gave only a small increase in desorption. This result shows that enzyme removal readily occurs using low concentrations of surfactant.

Cabrera et al. [69] observed that the amount of surfactant for complete enzyme desorption depends on the type of biocatalyst produced. Depending on the biocatalyst, different concentrations of Triton X-100, ranging from 1 to $4 \%$, were employed for complete desorption of lipase. This aspect allows to evaluate the association enzyme-support from the point of view of the intermolecular interactions and the morphology of the support [31]. Considering the intermolecular interactions, the immobilization of LU on CTA occurs in a similar way to that observed for other hydrophobic polymers.

The easy removal of $85 \%$ of the enzyme allows the support to be reused in another enzymatic immobilization. The adsorption of enzymes by supports are strong enough to use the enzyme preparation as an immobilized one, although the enzyme may be desorbed by using detergents. This fact allows the reversibility of immobilization, which is one advantage of physical adsorption [44].

\subsection{CTA-LU Reuse}

In order to evaluate the reusability, CTA-LU was submitted to successive cycles of $p$-nitrophenyl palmitate ( $p$-NPP) hydrolysis (Figure 12).

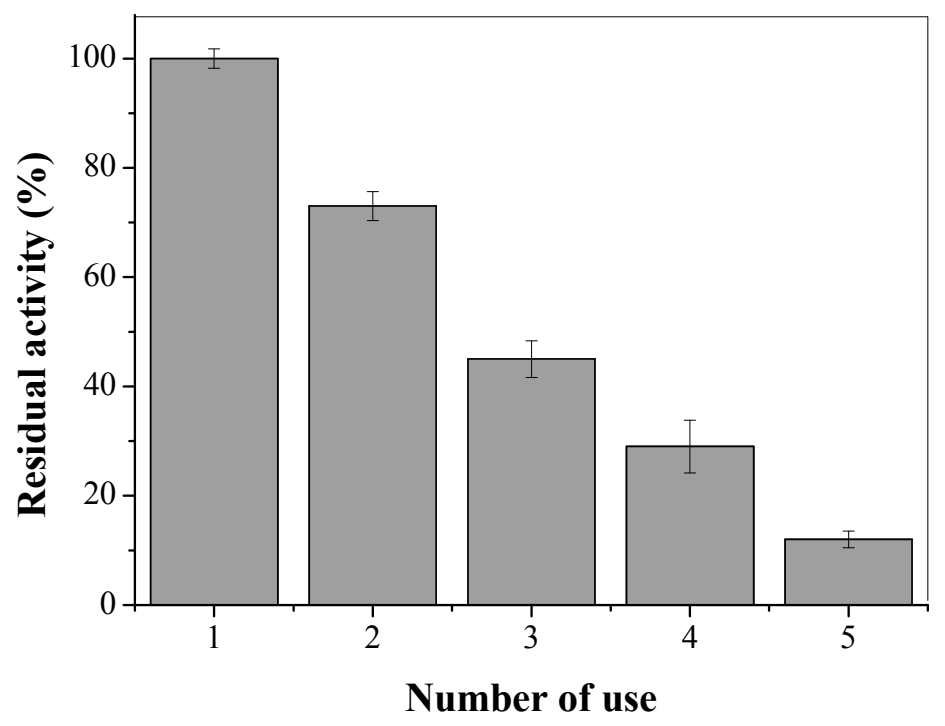

Figure 12. Reuse of CTA-LU on $p$-NPP hydrolysis. Reactions carried out as described in Section 2.6. The error bars are derived from triplicates.

CTA-LU showed constant activity decrease after each reaction cycle, retaining more than $50 \%$ of activity up to only two cycles. The activity loss may be related to enzyme release from CTA, possible caused by detergent $(0.25 \% v / v$ Triton X-100) used to prepare $p$-NPP substrate [70] and various steps of experiment. It was observed in Figure 11 that the desorption of CTA-LU is favored by the presented of Triton X-100. Turati et al. [71] also observed similar behave on immobilization of Lipase from Penicillium sp. Section Gracilenta (CBMAI 1583) by physical adsorption using Triton X-100 during substrate preparation.

Immobilization of lipases by physical adsorption has a main drawback: desorption of enzymes when exposed at high temperatures, or in presence of detergents, organic solvents, or some products of reactions [70]. Some heterofunctional supports have been proposed for solve or minimize this effects, having some groups (cationic/anionic groups [72], glutaraldehyde [73], glyoxyl [74], epoxide [75]). Fernandez-Lopez [76] recently proposed the production of the physical coating of 
lipases immobilized on octyl-agarose (OC) by using ionic polymers to physically crosslink different immobilized lipase molecules. The strategy permitted to avoid enzyme desorption, improving enzyme stability, but maintaining the reversibility of the immobilization.

\subsection{Methanolysis Product of Soybean Oil Catalyzed by LU Immobilized in CTA}

An evaluation of the production of FAME from soybean oil using CTA-LU (195 U/g of soybean oil) as catalyst was carried out. The products of the reaction were analyzed by gas chromatography with a flame ionization detector and the identity of each peak of methyl ester was confirmed by gas chromatography coupled with mass spectrometry.

The yields of methyl ester obtained was $43.8 \pm 0.6 \%$. The FAME content was calculated using the compensated normalization method with internal standardization based on the European standard EN 14103. Methyl heptadecanoate was used as the internal standard in this analysis.

Figure 13 shows the chromatographic profile of biodiesel produced from soybean oil methanolysis catalyzed by LU immobilized in CTA resulted in 5 peaks in the chromatogram.

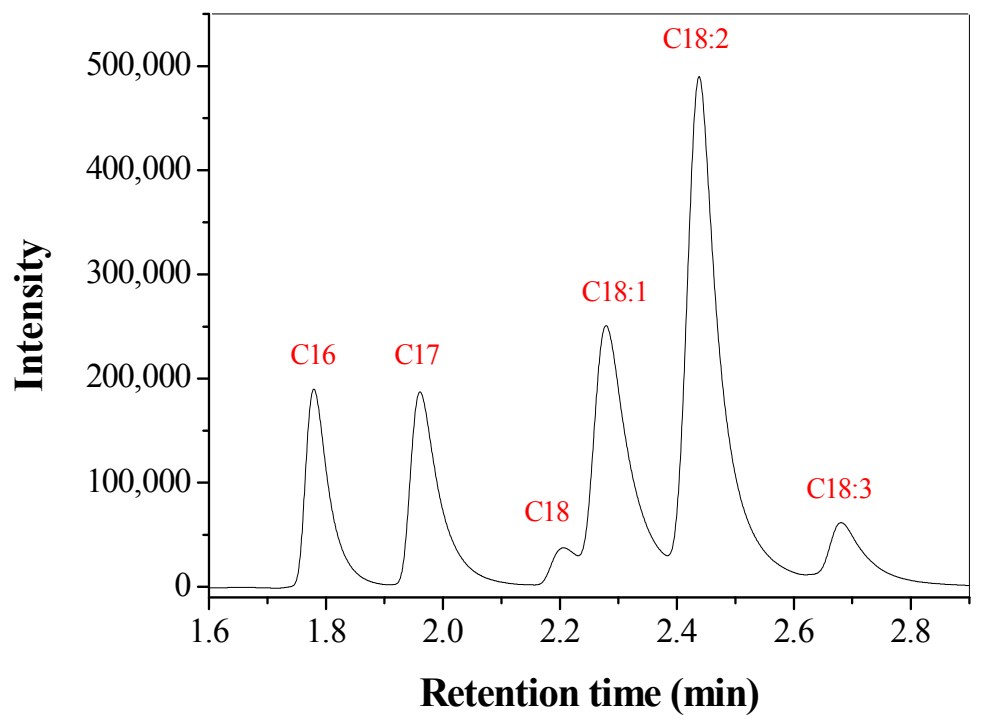

Figure 13. Chromatographic profile of esters formed in reactions catalyzed by LU immobilized on CTA during $24 \mathrm{~h}$. Chromatographic conditions: column oven temperature: $210^{\circ} \mathrm{C}$. Split injector: $250{ }^{\circ} \mathrm{C}$, split ratio 1:10; injected volume: $1.0 \mu \mathrm{L}$.

It is possible to observe peaks corresponding to the main fatty acid esters of soybean oil: C16, C18, C18:1, C18:2 and C18:3 (palmitic, stearic, oleic, linoleic and linolenic acids, respectively). The chromatographic profile of biodiesel obtained from soybean oil catalyzed by LU immobilized on CTA is similar to that obtained from soybean biodiesel via alkaline catalysis [77]. This result indicates transesterification of soybean oil by CTA-LU.

LU is an enzyme that has phospholipid and lipid activity being able to hydrolyze esters of carboxylic acids as well as phosphates of esters of fatty acids. In the literature, it is suggested that Lecitase Ultra has a single active site which possesses both lipase and phospholipase activities [44]. The enzymatic production of biodiesel depends on enzyme and media, in the case of LU, the existence of a single active site for both activities would possibly make the system even more sensitive to the medium conditions. It is important to emphasize that LU presents, under specific conditions, good catalytic capacity to produce methyl esters, similar to those observed for commercial enzymes prepared only for this purpose [46].

Although Lecitase ultra is a phospholipase, it has lipolytic activity and shown to be capable of producing methyl esters from commercial soybean oil. The \% FAME obtained in this work is relatively 
low that any others obtained with other lipases [78-80]. Nevertheless, compared to results using LU in other supports, or even immobilized in another way, such production is acceptable. Tacias-pascacio and collaborators [46] recently evaluated immobilized LU in the production of biodiesel from used cooking oil. After $24 \mathrm{~h}$ at $30{ }^{\circ} \mathrm{C}$ with stirring, using $2 \mathrm{~g}$ of oil, $10 \%$ of the biocatalyst ( $w / w$ of oil), $0.25 \%$ of water ( $w / w$ of oil), 3:1 methanol:oil molar ratio and $3 \mathrm{~mL}$ of hexane, the maximum yield obtained was $11 \%$, when LU was immobilized in macroporous styrene and octadecyl methacrylate, being this value lower than the $44 \%$ obtained in this work with the same solvent using CTA as support. These results suggest that the immobilized LU in CTA shows good performance in biodiesel production under the conditions tested. Anyway, studies using other sources and/or other protocols of immobilization, especially with heterofunctional groups, would be interesting in the future.

\section{Conclusions}

Immobilization of phospholipase, Lecitase Ultra (LU) in Cellulose Triacetate (CTA) opens perspectives for the application of CTA as a support for this enzyme and permits the use of this biocatalyst in several esterification, hydrolysis and transesterification processes. The immobilization of LU in CTA was efficient, reaching $97 \%$ with 60 min of contact. The adsorption process was efficient and reversible, so the enzyme could be removed from support using Triton X-100. The immobilized enzyme exhibits higher thermal stability than free lipase. This aspect was observed by shifting of the optimum temperature of the enzyme from 35 (free enzyme) to $40{ }^{\circ} \mathrm{C}$ (immobilized enzyme). The difference observed for immobilized enzyme compared to free one, in relation to temperature and incubation time, showed the efficiency of the immobilization and the stabilization of LU adsorbed on CTA. In this sense, the enzymatic activity for LU was tested using soybean oil as a substrate. The transesterification reaction with methanol occurred with production of $43.8 \%$ of FAME. Although Lecitase ultra is a phospholipase, it has lipolytic activity and shown to be capable of producing methyl esters from commercial soybean oil.

Acknowledgments: The authors thank the CAPES for financial support; CNPq (406838/2013-5); Microscopy Laboratory of Chemical Engineering of Uberlândia Federal University for SEM analysis; Ricardo Soares for the use of GCMS; Vicelma Luiz Cardoso and Miria Hespanhol for allowing the use of their GC.

Author Contributions: Francielle Batista da Silva, Wilson Galvão de Morais Júnior and Cleuzilene Vieira da Silva conceived and designed the experiments; Andressa Tironi Vieira and Antônio Carlos Ferreira Batista studied process and analyzed data; Francielle Batista da Silva, Anízio Márcio de Faria and Rosana Maria Nascimento Assunção wrote the paper.

Conflicts of Interest: The authors declare no conflict of interest.

\section{References}

1. Ribeiro, S.D.; Guimes, R.F.; Meneguin, A.B.; Prezotti, F.G.; Boni, F.I.; Cury, B.S.F.; Gremião, M.P.D. Cellulose triacetate films obtained from sugarcane bagasse: Evaluation as coating and mucoadhesive material for drug delivery systems. Carbohydr. Polym. 2016, 152, 764-774. [CrossRef] [PubMed]

2. Rodrigues Filho, G.; Ribeiro, S.D.; da Silva Meireles, C.; da Silva, L.G.; Ruggiero, R.; Ferreira, M.F.; Cerqueira, D.A.; de Assunção, R.M.N.; Zeni, M.; Polleto, P. Release of doxycycline through cellulose acetate symmetric and asymmetric membranes produced from recycled agroindustrial residue: Sugarcane bagasse. Ind. Crops Prod. 2011, 33, 566-571. [CrossRef]

3. Candido, R.G.; Godoy, G.G.; Gonçalves, A.R. Characterization and application of cellulose acetate synthesized from sugarcane bagasse. Carbohydr. Polym. 2017, 167, 280-289. [CrossRef] [PubMed]

4. Cheng, H.N.; Dowd, M.K.; Selling, G.W.; Biswas, A. Synthesis of cellulose acetate from cotton byproducts. Carbohydr. Polym. 2010, 80, 449-452. [CrossRef]

5. Je, H.H.; Noh, S.; Hong, S.; Ju, Y.; Kim, J.; Hwanga, D.S. Cellulose nanofibers for magnetically-separable and highly loaded enzyme immobilization. Chem. Eng. J. 2017, 323, 425-433. [CrossRef]

6. Prasetyo, E.N.; Semlitsch, S.; Nyanhongo, G.S.; Lemmouchi, Y.; Guebitza, G.M. Laccase functionalized cellulose acetate for the removal of toxic combustion products. React. Funct. Polym. 2015, 97, 12-18. [CrossRef] 
7. Huang, W.; Zhan, Y.; Shi, X.; Chen, J.; Deng, H.; Du, Y. Controllable immobilization of naringinase on electrospun cellulose acetate nanofibers and their application to juice debittering. Int. J. Biol. Macromol. 2017, 98, 630-636. [CrossRef] [PubMed]

8. Da Silva Meireles, C. Síntese e Caracterização de Membranas de Acetato de Celulose, Obtido do Bagaço de Cana-de-Açúcar, e Blendas de Acetato de Celulose com Poliestireno de Copos Plásticos Descartados. Ph.D. Thesis, Federal University of Uberlandia, Uberlandia, Brazil, 2007.

9. Zhou, X.; Lin, X.; White, K.L.; Lin, S.; Wu, H.; Cao, S.; Huang, L.; Chen, L. Effect of the degree of substitution on the hydrophobicity of acetylated cellulose for production of liquid marbles. Cellulose 2016, 23, 811-821. [CrossRef]

10. Kosaka, P.M.; Kawano, Y.; El Seoud, O.A.; Petri, D.F.S. Catalytic Activity of Lipase Immobilized onto Ultrathin Films of Cellulose Esters. Langmuir 2007, 23, 12167-12173. [CrossRef] [PubMed]

11. Cerveró, J.M.; Álvarez, J.R.; Luque, S. Novozym 435-catalyzed synthesis of fatty acid ethyl esters from soybean oil for biodiesel production. Biomass Bioenergy 2014, 61, 131-137. [CrossRef]

12. Haigh, K.F.; Vladisavljević, G.T.; Reynolds, J.C.; Nagy, Z.; Saha, B. Kinetics of the pre-treatment of used cooking oil using Novozyme 435 for biodiesel production. Chem. Eng. Res. Des. 2014, 92, 713-719. [CrossRef]

13. Hernández-Martín, E.; Otero, C. Different enzyme requirements for the synthesis of biodiesel: Novozym ${ }^{\circledR} 435$ and Lipozyme ${ }^{\circledR}$ TL IM. Bioresour. Technol. 2008, 99, 277-286. [CrossRef] [PubMed]

14. Castillo López, B.; Esteban Cerdán, L.; Robles Medina, A.; Navarro López, E.; Martín Valverde, L.; Hita Peña, E.; González Moreno, P.A.; Molina Grima, E. Production of biodiesel from vegetable oil and microalgae by fatty acid extraction and enzymatic esterification. J. Biosci. Bioeng. 2015, 119, 706-711. [CrossRef] [PubMed]

15. Verdasco-Martín, C.M.; Villalba, M.; dos Santos, J.C.S.; Tobajas, M.; Fernandez-Lafuente, R.; Otero, C. Effect of chemical modification of Novozym 435 on its performance in the alcoholysis of camelina oil. Biochem. Eng. J. 2016, 111, 75-86. [CrossRef]

16. Manurung, R.; Hasibuan, R.; Taslim, T.; Rahayu, N.S.; Darusmy, A. Enzymatic Transesterification of DPO to Produce Biodiesel by Using Lipozyme RM IM in Ionic Liquid System. Procedia Soc. Behav. Sci. 2015, 195, 2485-2491. [CrossRef]

17. Ungcharoenwiwat, P.; Canyuk, B.; H-Kittikun, A. Synthesis of jatropha oil based wax esters using an immobilized lipase from Burkholderia sp. EQ3 and Lipozyme RM IM. Process Biochem. 2016, 51, 392-398. [CrossRef]

18. Cipolatti, E.P.; Manoel, E.A.; Fernandez-Lafuente, R.; Freire, D.M.G. Support engineering: Relation between development of new supports for immobilization of lipases and their applications. Biotechnol. Res. Innov. 2017, 1-9. [CrossRef]

19. Badgujar, K.C.; Bhanage, B.M. Synthesis of geranyl acetate in non-aqueous media using immobilized Pseudomonas cepacia lipase on biodegradable polymer film: Kinetic modelling and chain length effect study. Process Biochem. 2014, 49, 1304-1313. [CrossRef]

20. Kim, H.J.; Park, S.; Kim, S.H.; Kim, J.H.; Yu, H.; Kim, H.J.; Yang, Y.-H.; Kan, E.; Kim, Y.H.; Lee, S.H. Biocompatible cellulose nanocrystals as supports to immobilize lipase. J. Mol. Catal. B Enzym. 2015, 122, 170-178. [CrossRef]

21. Kosaka, P.M. Aplicações e Caracterização de Ésteres de Celulose. Ph.D. Thesis, Universidade de São Paulo, São Paulo, Brasil, 2007.

22. Kosaka, P.M.; Kawano, Y.; Salvadori, M.C.; Petri, D.F.S. Characterization of Ultrathin Films of Cellulose Esters. Cellulose 2005, 12, 351-359. [CrossRef]

23. Baron, A.M. Preparação e Caracterização de Lipases Imobilizadas Para Utilização em Biocatálise. Ph.D. Thesis, Federal University of Paraná, Curitiba, Brazil, 2008.

24. Palomo, J.M.; Segura, R.L.; Mateo, C.; Terreni, M.; Guisan, J.M.; Fernández-Lafuente, R. Synthesis of enantiomerically pure glycidol via a fully enantioselective lipase-catalyzed resolution. Tetrahedron Asymmetry 2005, 16, 869-874. [CrossRef]

25. Yousefi, M.; Mohammadi, M.; Habibi, Z. Enantioselective resolution of racemic ibuprofen esters using different lipases immobilized on octyl sepharose. J. Mol. Catal. B Enzym. 2014, 104, 87-94. [CrossRef]

26. Velasco-Lozano, S.; López-Gallego, F.; Rocha-Martin, J.; Guisán, J.M.; Favela-Torres, E. Improving enantioselectivity of lipase from Candida rugosa by carrier-bound and carrier-free immobilization. J. Mol. Catal. B Enzym. 2016, 130, 32-39. [CrossRef] 
27. Mateo, C.; Palomo, J.M.; Fernandez-Lorente, G.; Guisan, J.M.; Fernandez-Lafuente, R. Improvement of enzyme activity, stability and selectivity via immobilization techniques. Enzym. Microb. Technol. 2007, 40, 1451-1463. [CrossRef]

28. Nigam, S.; Mehrotra, S.; Vani, B.; Mehrotra, R. Lipase Immobilization Techniques for Biodiesel Production: An Overview. IBIMA Publ. Int. J. Renew. Energy Biofuels 2014, 2014. [CrossRef]

29. Fernandez-Lafuente, R.; Armisén, P.; Sabuquillo, P.; Fernández-Lorente, G.; Guisán, J.M. Immobilization of lipases by selective adsorption on hydrophobic supports. Chem. Phys. Lipids 1998, 93, 185-197. [CrossRef]

30. Derewenda, U.; Brzozowski, A.M.; Lawson, D.M.; Derewenda, Z.S. Catalysis at the interface: The anatomy of a conformational change in a triglyceride lipase. Biochemistry 1992, 31, 1532-1541. [CrossRef] [PubMed]

31. Palomo, J.M.; Munõz, G.; Fernández-Lorente, G.; Mateo, C.; Fernández-Lafuente, R.; Guisán, J.M. Interfacial adsorption of lipases on very hydrophobic support (octadecyl-Sepabeads): Immobilization, hyperactivation and stabilization of the open form of lipases. J. Mol. Catal. B Enzym. 2002, 19-20, 279-286. [CrossRef]

32. Miled, N.; Beisson, F.; de Caro, J.; de Caro, A.; Arondel, V.; Verger, R. Interfacial catalysis by lipases. J. Mol. Catal. B Enzym. 2001, 11, 165-171. [CrossRef]

33. Liu, N.; Wang, Y.; Zhao, Q.; Cui, C.; Fu, M.; Zhao, M. Immobilisation of lecitase ${ }^{\circledR}$ ultra for production of diacylglycerols by glycerolysis of soybean oil. Food Chem. 2012, 134, 301-307. [CrossRef]

34. Dos Santos, J.C.S.; Garcia-Galan, C.; Rodrigues, R.C.; de Sant'Ana, H.B.; Gonçalves, L.R.B.; Fernandez-Lafuente, R. Stabilizing hyperactivated lecitase structures through physical treatment with ionic polymers. Process Biochem. 2014, 49, 1511-1515. [CrossRef]

35. Yang, J.-G.; Wang, Y.-H.; Yang, B.; Mainda, G.; Guo, Y. Degumming of vegetable oil by a new microbial lipase. Food Technol. Biotechnol. 2016, 44, 101-104.

36. Yang, B.; Wang, Y.-H.; Yang, J.-G. Optimization of enzymatic degumming process for rapeseed oil. J. Am. Oil Chem. Soc. 2006, 83, 653-658. [CrossRef]

37. Lamas, D.L.; Crapiste, G.H.; Constenla, D.T. Changes in quality and composition of sunflower oil during enzymatic degumming process. LWT Food Sci. Technol. 2014, 58, 71-76. [CrossRef]

38. Sampaio, K.A.; Zyaykina, N.; Wozniak, B.; Tsukamoto, J.; Greyt, W.D.; Stevens, C.V. Enzymatic degumming: Degumming efficiency versus yield increase. Eur. J. Lipid Sci. Technol. 2015, 117, 81-86. [CrossRef]

39. Li, Z.; Liu, H.; Zhao, G.; Wang, P.; Wang, L.; Wu, H.; Fang, X.; Sun, X.; Wu, X.; Zheng, Z. Enhancing the performance of a phospholipase A1 for oil degumming by bio-imprinting and immobilization. J. Mol. Catal. B Enzym. 2016, 123, 122-131. [CrossRef]

40. Liu, N.; Wang, Y.; Zhao, Q.; Zhao, M. Production of palm oil-based diacylglycerol using Lecitase Ultra-catalyzed glycerolysis and molecular distillation. Food Sci. Biotechnol. 2014, 23, 365-371. [CrossRef]

41. Gonçalves, K.M.; Sutili, F.K.; Júnior, I.I.; Flores, M.C.; Soter de Mariz e Miranda, L.; Leal, I.C.R.; Cordeiro, Y.; Luque, R.; Alves de Souza, R.O.M. A Comprehensive study on the activity and deactivation of immobilized lecitase ultra in esterifications of food waste streams to monoacylglycerols. ChemSusChem 2013, 6, 872-879. [CrossRef] [PubMed]

42. Wang, L.; Wang, Y.; Hu, C.; Cao, Q.; Yang, X.; Zhao, M. Preparation of diacylglycerol-enriched oil from free fatty acids using lecitase ultra-catalyzed esterification. J. Am. Oil Chem. Soc. 2011, 88, 1557-1565. [CrossRef]

43. Mishra, M.K.; Harini, M.; Kumaraguru, T.; Lakshmi Prasanna, T.; Fadnavis, N.W. A porous vessel bioreactor for gel entrapped biocatalysts: Kinetic resolution of trans-methyl (4-methoxyphenyl)glycidate by Lecitase ${ }^{\circledR}$ Ultra in gelatin organogel (Gelozyme). J. Mol. Catal. B Enzym. 2011, 71, 56-62. [CrossRef]

44. Mishra, M.K.; Kumaraguru, T.; Sheelu, G.; Fadnavis, N.W. Lipase activity of Lecitase ${ }^{\circledR}$ Ultra: Characterization and applications in enantioselective reactions. Tetrahedron Asymmetry 2009, 20, 2854-2860. [CrossRef]

45. Hirata, D.B.; Albuquerque, T.L.; Rueda, N.; Virgen-Ortíz, J.J.; Tacias-Pascacio, V.G.; Fernandez-Lafuente, R. Evaluation of different immobilized lipases in transesterification reactions using tributyrin: Advantages of the heterofunctional octyl agarose beads. J. Mol. Catal. B Enzym. 2016, 133, 117-123. [CrossRef]

46. Tacias-Pascacio, V.G.; Virgen-Ortíz, J.J.; Jiménez-Pérez, M.; Yates, M.; Torrestiana-Sanchez, B.; Rosales-Quintero, A.; Fernandez-Lafuente, R. Evaluation of different lipase biocatalysts in the production of biodiesel from used cooking oil: Critical role of the immobilization support. Fuel 2017, 200, 1-10. [CrossRef]

47. Fernandez-Lorente, G.; Palomo, J.M.; Guisan, J.M.; Fernandez-Lafuente, R. Effect of the immobilization protocol in the activity, stability, and enantioslectivity of Lecitase ${ }^{\circledR}$ Ultra. J. Mol. Catal. B Enzym. 2007, 47, 99-104. [CrossRef] 
48. Ikeda, Y.; Kurokawa, Y. Synthesis of geranyl acetate by lipase entrap-immobilized in cellulose acetate-TiO gel fiber. J. Am. Oil Chem. Soc. 2001, 78, 1099-1103. [CrossRef]

49. Singh, A.K.; Mukhopadhyay, M. Immobilization of Candida antarctica lipase onto cellulose acetate-coated $\mathrm{Fe}_{2} \mathrm{O}_{3}$ nanoparticles for glycerolysis of olive oil. Korean J. Chem. Eng. 2014, 31, 1225-1232. [CrossRef]

50. Cerqueira, D.A.; Rodrigues Filho, G.; da Silva Meireles, C. Optimization of sugarcane bagasse cellulose acetylation. Carbohydr. Polym. 2007, 69, 579-582. [CrossRef]

51. Hurtubise, F.G. The analytical and structural aspects of the infrared spectroscopy of cellulose acetate. Tappi 1962,45 .

52. Cerqueira, D.A.; Rodrigues Filho, G.; de A. Carvalho, R.; Valente, A.J.M. Caracterização de acetato de celulose obtido a partir do bagaço de cana-de-açúcar por ${ }^{1} \mathrm{H}-\mathrm{RMN}$. Polímeros 2010, 20, 85-91. [CrossRef]

53. Pereira, M.G.; Facchini, F.D.A.; Filó, L.E.C.; Polizeli, A.M.; Vici, A.C.; Jorge, J.A.; Fernandez-Lorente, G.; Pessela, B.C.; Guisan, J.M.; Polizeli, M.; et al. Immobilized lipase from Hypocrea pseudokoningii on hydrophobic and ionic supports: Determination of thermal and organic solvent stabilities for applications in the oleochemical industry. Process Biochem. 2015, 50, 561-570. [CrossRef]

54. Pencreac'h, G.; Baratti, J.C. Hydrolysis of $p$-nitrophenyl palmitate in $n$-heptane by the Pseudomonas cepacia lipase: A simple test for the determination of lipase activity in organic media. Enzym. Microb. Technol. 1996, 18, 417-422. [CrossRef]

55. Bradford, M.M. A rapid and sensitive method for the quantitation of microgram quantities of protein utilizing the principle of protein-dye binding. Anal. Biochem. 1976, 72, 248-254. [CrossRef]

56. Batista, K.A.; Purcena, L.L.A.; Alves, G.L.; Fernandes, K.F. A pectin-lipase derivative as alternative copolymer for lipase assay. J. Mol. Catal. B Enzym. 2014, 102, 25-32. [CrossRef]

57. Ribeiro, E.A.M.; Filho, G.R.; Vieira, J.G.; de Sousa, R.M.F.; de Assunção, R.M.N.; da Silva Meireles, C.; Duarte, J.; Zeni, M. Characterization of asymmetric membranes of cellulose acetate from recycling of residue corn stover for use in ultrafiltration. Quim. Nova 2014, 37, 385-391. [CrossRef]

58. Da Cruz, A.C.; da Silva Meireles, C.; Ribeiro, S.D.; Rodrigues Filho, G.; de Assunção, R.M.N.; Cerqueira, D.A.; Zeni, M.; Poletto, P. Utilização do acetato de celulose produzido a partir da celulose extraída do caroço de manga como matriz para produção de sistemas microparticulados. Quim. Nova 2011, 34, 385-389. [CrossRef]

59. Ferreira Júnior, M.F.; Mundim, E.A.R.; Filho, G.R.; da Silva Meireles, C.; Cerqueira, D.A.; de Assunção, R.M.N.; Marcolin, M.; Zeni, M. SEM study of the morphology of asymmetric cellulose acetate membranes produced from recycled agro-industrial residues: Sugarcane bagasse and mango seeds. Polym. Bull. 2011, 66, 377-389. [CrossRef]

60. Fischer, S.; Thümmler, K.; Volkert, B.; Hettrich, K.; Schmidt, I.; Fischer, K. Properties and applications of cellulose acetate. Macromol. Symp. 2008, 262, 89-96. [CrossRef]

61. Kamide, K.; Okajima, K.; Saito, M. Nuclear Magnetic Resonance Study of Thermodynamic Interaction between Cellulose Acetate and Solvent. Polym. J. 1981, 13, 115-125. [CrossRef]

62. Puleo, A.C.; Paul, D.R.; Kelley, S.S. The effect of degree of acetylation on gas sorption and transport behavior in cellulose acetate. J. Membr. Sci. 1989, 47, 301-332. [CrossRef]

63. Manoel, E.A.; dos Santos, J.C.S.; Freire, D.M.G.; Rueda, N.; Fernandez-Lafuente, R. Immobilization of lipases on hydrophobic supports involves the open form of the enzyme. Enzym. Microb. Technol. 2015, 71, 53-57. [CrossRef] [PubMed]

64. Aybastıer, Ö.; Demir, C. Optimization of immobilization conditions of Thermomyces lanuginosus lipase on styrene-Divinylbenzene copolymer using response surface methodology. J. Mol. Catal. B Enzym. 2010, 63, 170-178. [CrossRef]

65. Cipolatti, E.P.; Moreno-Pérez, S.; de Andrade Souza, L.T.; Valério, A.; Guisán, J.M.; de Araújo, P.H.H.; Sayer, C.; Ninow, J.L.; de Oliveira, D.; Pessela, B.C. Synthesis and modification of polyurethane for immobilization of Thermomyces lanuginosus (TLL) lipase for ethanolysis of fish oil in solvent free system. J. Mol. Catal. B Enzym. 2015, 122, 163-169. [CrossRef]

66. Nicoletti, G.; Cipolatti, E.P.; Valério, A.; Carbonera, N.T.G.; Soares, N.S.; Theilacker, E.; Ninow, J.L.; de Oliveira, D. Evaluation of different methods for immobilization of Candida antarctica lipase B (CalB lipase) in polyurethane foam and its application in the production of geranyl propionate. Bioprocess Biosyst. Eng. 2015, 38, 1739-1748. [CrossRef] [PubMed] 
67. Garcia-Galan, C.; dos Santos, J.C.S.; Barbosa, O.; Torres, R.; Pereira, E.B.; Corberan, V.C.; Gonçalves, L.R.B.; Fernandez-Lafuente, R. Tuning of Lecitase features via solid-phase chemical modification: Effect of the immobilization protocol. Process Biochem. 2014, 49, 604-616. [CrossRef]

68. Salihu, A.; Alam, M.Z. Solvent tolerant lipases: A review. Process Biochem. 2015, 50, 86-96. [CrossRef]

69. Cabrera, Z.; Fernandez-Lorente, G.; Fernandez-Lafuente, R.; Palomo, J.M.; Guisan, J.M. Novozym 435 displays very different selectivity compared to lipase from Candida antarctica B adsorbed on other hydrophobic supports. J. Mol. Catal. B Enzym. 2009, 57, 171-176. [CrossRef]

70. Virgen-Ortíz, J.J.; Tacias-Pascacio, V.G.; Hirata, D.B.; Torrestiana-Sanchez, B.; Rosales-Quintero, A.; Fernandez-Lafuente, R. Relevance of substrates and products on the desorption of lipases physically adsorbed on hydrophobic supports. Enzym. Microb. Technol. 2017, 96, 30-35. [CrossRef] [PubMed]

71. Turati, D.; Morais Júnior, W.; Terrasan, C.; Moreno-Perez, S.; Pessela, B.; Fernandez-Lorente, G.; Guisan, J.; Carmona, E. Immobilization of Lipase from Penicillium sp. Section Gracilenta (CBMAI 1583) on Different Hydrophobic Supports: Modulation of Functional Properties. Molecules 2017, 22, 339. [CrossRef] [PubMed]

72. Rueda, N.; dos Santos, C.S.; Rodriguez, M.D.; Albuquerque, T.L.; Barbosa, O.; Torres, R.; Ortiz, C.; Fernandez-Lafuente, R. Reversible immobilization of lipases on octyl-glutamic agarose beads: A mixed adsorption that reinforces enzyme immobilization. J. Mol. Catal. B Enzym. 2016, 128, 10-18. [CrossRef]

73. Vescovi, V.; Kopp, W.; Guisán, J.M.; Giordano, R.L.C.; Mendes, A.A.; Tardioli, P.W. Improved catalytic properties of Candida antarctica lipase B multi-attached on tailor-made hydrophobic silica containing octyl and multifunctional amino-glutaraldehyde spacer arms. Process Biochem. 2016, 51, 2055-2066. [CrossRef]

74. Bernal, C.; Illanes, A.; Wilson, L. Heterofunctional Hydrophilic-Hydrophobic Porous Silica as Support for Multipoint Covalent Immobilization of Lipases: Application to Lactulose Palmitate Synthesis. Langmuir 2014, 30, 3557-3566. [CrossRef] [PubMed]

75. Guajardo, N.; Bernal, C.; Wilson, L.; Cabrera, Z. Selectivity of R- $\alpha$-monobenzoate glycerol synthesis catalyzed by Candida antarctica lipase B immobilized on heterofunctional supports. Process Biochem. 2015, 50, 1870-1877. [CrossRef]

76. Fernandez-Lopez, L.; Pedrero, S.G.; Lopez-Carrobles, N.; Virgen-Ortíz, J.J.; Gorines, B.C.; Otero, C.; Fernandez-Lafuente, R. Physical crosslinking of lipase from Rhizomucor miehei immobilized on octyl agarose via coating with ionic polymers. Process Biochem. 2017, 54, 81-88. [CrossRef]

77. Santos, R.C.R.; Vieira, R.B.; Valentini, A. Monitoring the conversion of soybean oil to methyl or ethyl esters using the refractive index with correlation gas chromatography. Microchem. J. 2013, 109, 46-50. [CrossRef]

78. Wang, Y.; Liu, J.; Gerken, H.; Zhang, C.; Hu, Q.; Li, Y. Highly-efficient enzymatic conversion of crude algal oils into biodiesel. Bioresour. Technol. 2014, 172, 143-149. [CrossRef] [PubMed]

79. Talukder, M.M.R.; Wu, J.C.; Fen, N.M.; Melissa, Y.L.S. Two-step lipase catalysis for production of biodiesel. Biochem. Eng. J. 2010, 49, 207-212. [CrossRef]

80. Purwanto, M.G.M.; Maretha, M.V.; Wahyudi, M.; Goeltom, M.T. Whole Cell Hydrolysis of Sardine (Sardinella Lemuru) Oil Waste Using Mucor Circinelloides NRRL 1405 Immobilized in Poly-urethane Foam. Procedia Chem. 2015, 14, 256-262. [CrossRef]

Sample Availability: Samples of the support are available from the authors.

(C) 2017 by the authors. Licensee MDPI, Basel, Switzerland. This article is an open access article distributed under the terms and conditions of the Creative Commons Attribution (CC BY) license (http://creativecommons.org/licenses/by/4.0/). 